\title{
Survivability of
}

Ancient Man-Made Earthen Mounds: Implications for

Uranium Mill Tailings Impoundments

Prepared by C. G. Lindsey, J. Mishima, S. E. King, W. H. Walters

Pacific Northwest Laboratory

Operated by

Battelle Memorial Institute

Prepared for

U.S. Nuclear Regulatory

Commission 


\section{NOTICE}

This report was prepared as an account of work sponsored by an agency of the United States Government. Neither the United States Government nor any agency thereof, or any of their employees, makes any warranty, expressed or implied, or assumes any legal liability of responsibility for any third party's use, or the results of such use, of any information, apparatus, product or process disclosed in this report, or represents that its use by such third party would not infringe privately owned rights.

\section{Availability of Reference Materials Cited in NRC Publications}

Most documents cited in NRC publications will be available from one of the following sources:

1. The NRC Public Document Room, 1717 H Street, N.W. Washington, DC 20555

2. The NRC/GPO Sales Program, U.S. Nuclear Regulatory Commission, Washington, DC 20555

3. The National Technical Information Service, Springfield, VA 22161

Although the listing that follows represents the majority of clocuments cited in NAC publications, it is not intended to be exhaustive.

Referenced documents available for inspection and copying for a fee from the NRC Public Document Room include NRC correspondence and internal NRC memoranda; NRC Office of Inspection and Enforcement bulletins, circulars, information notices, inspection and investigation notices; Licensee Event Reports; vendor reports and correspondence; Commission papers; and applicant and licensee documents and correspondence.

The following documents in the NUREG series are available for purchase from the NRC/GPO Sales Program: formal NRC staff and contractor reports, NRC-sponsored conference proceedings, and NRC booklets and brochures. Also available are Regulatory Guides, NRC regulations in the Code of Federal Regulations, and Nuclear Regulatory Commission /seuances.

Documents available from the National Technical Information Service include NUREG series reports and technical reports prepared by other federal agencies and reports prepared by the Atomic Energy Commission, forerunner agency to the Nuclear Regulatory Commission.

Documents available from public and special technical libraries include all open literature items, such as books, journal and periodical articles, and transactions. Federa/ Register notices, federal and state legislation, and congressional reports can usually be obtained from these libraries.

Documents such as theses, dissertations, foreign reports and translations, and non-NRC conference proceedings are available for purchase from the organization sponsoring the publication cited.

Single copies of NRC draft reports are available free upon written request to the Division of Technical Information and Document Control, U.S. Nuclear Regulatory Commission, Washington, DC 20555.

Copies of industry codes and standards used in a substantive manner in the NRC regulatory process are maintained at the NRC Library, 7920 Norfolk Avenue, Bethesda, Maryland, and are available there for reference use by the public. Codes and standards are usually copyrighted and may be purchased from the originating organization or, if they are American National Standards, from the American National Standards Institute. 1430 Broadway, New York, NY 10018. 
NUREG/CR-3061

PNL-4541

RU

Survivability of

Ancient Man-Made Earthen Mounds:

Implications for

Uranium Mill Tailings Impoundments

Manuscript Completed: November 1983

Date Published: June 1983

Prepared by

C. G. Lindsey, J. Mishima, S. E. King, W. H. Walters

Pacific Northwest Laboratory

Richland, WA 99352

\section{Prepared for}

Division of Health, Siting, and Waste Management

Office of Nuclear Regulatory Research

U.S. Nuclear Regulatory Commission

Washington, D.C. 20555

NRC FIN B2370 



\section{ABSTRACT}

As part of a study for the Nuclear Regulatory Commission (NRC), the Pacific Northwest Laboratory (PNL) is investigating long-term stabilization techniques for uranium mill tailings impoundments. Part of this investigation involves the design of a rock armoring blanket (riprap) to mitigate wind and water erosion of the underlying soil cover, which in turn prevents exposure of the tailings to the environment. However, the need for the armoring blanket, as well as the blanket's effectiveness, depends on the stability of the underlying soil cap (radon suppression cover) and on the tailings themselves. Compelling evidence in archaeological records suggests that large man-made earthen structures can remain sound and intact for time periods comparable to those required for the stabilization of the tailings piles if properly constructed.

In this report we present archaeological evidence on the existence and survivability of man-made earthen and rock structures through specific examples of such structures from around the world. We also review factors contributing to their survival or destruction and address the influence of climate, building materials, and construction techniques on survivability. 

Pacific Northwest Laboratory (PNL) is studying the long-term stability of uranium mill tailings impoundments. One aspect of PNL's study concerns mitigating the wind and water erosion of an earthen radon suppression cover placed over the tailings, by applying a rock armoring blanket (riprap) over the earthen cap. Throughout these studies, however, questions remain concerning the long-term structural integrity of the impoundments themselves. This report reviews archaeological data for examples of prehistoric man-made structures to determine if earthen mounds can survive hundreds to thousands of years of weathering and erosion and if so, to summarize the design and construction practices which promote or detract from the survival.

Man has been building earthen structures for several millenia. Hundreds of thousands of earthen mound sites and rock structures, some dating back as far as 3500 B.C., have been documented by archaeologists. Available evidence indicates that the survival rate of these mounds has been remarkably high. In the United States alone, thousands of ancient earthen mounds are found east of the Mississippi River, at least one of which is over 3000 years old. Many mound sites in the eastern United States are of sizes comparable to uranium tailings impoundments.

The reasons for the survival of prehistoric mounds are not well understood, mostly because archaeological studies have focused on the cultural significance of the sites, rather than on their ability to survive. Evidence does suggest that although natural erosional forces have affected these structures, the activities of man may have contributed most to the destruction of ancient mounds. Climate, building materials, and construction techniques also influence survivability. Vegetation has generally had a stabilizing effect on ancient mounds in the eastern United States, except where deeply rooted trees have developed.

of particular interest to this study is the use of clay caps and layers of rock covers on some ancient mounds, because rock cover and clay are proposed as components of long-term stabilization techniques for uranium tailings impoundments. This lends support to the assumption that riprapped impoundments, many of which are located in semi-arid or alpine climates, can survive long periods of exposure to natural weathering and erosional forces. 

CONTENTS

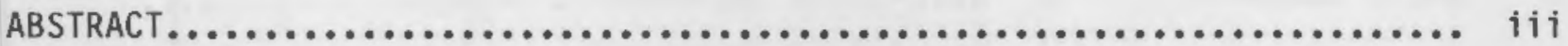

SUMMARY.................................................... v

INTRODUCTION................................................... 1

CONCLUSIONS ANO RECOMMENOATIONS.................................. 3

COMPONENTS OF URANIUM TAILINGS IMPOUNDMENTS...................... 5

CONSTRUCTION METHODS...................................... 5

SOIL COVERS............................................ 6

COMPONENTS OF ANCIENT EARTHEN MOUNDS............................. 7

ANCIENT MOUNDS IN EUROPE, AFrICA, AND THE NEAR EAST.$\ldots \ldots \ldots \ldots \ldots \ldots \ldots .9$

EUROPEAN MOUND CONSTRUCTION................................ g

Burial Mounds-Poland................................. 9

Mound Construction-British Isles......................... 10

RUSSIAN STEPPES/TRANSCAUCASUS............................. 14

ASIA MINOR................................................ 16

NORTH AFRICA........................................... 17

EASTERN AMERICAN PREHISTORIC EARTHWORKS......................... 19

EXAMPLES OF MOUND CONSTRUCTION IN THE EASTERN UNITED STATES........ 19

Poverty Point, Louisiana - 1500 B.C. to 1000 B.C.............. 19

Adena and Hopewell Sites - 1000 B.C. to A.D. $700 . \ldots \ldots \ldots \ldots . . .21$

The Mississippian Tradition - A.D. 700 to $1700 \ldots \ldots \ldots \ldots \ldots$......... 21

MOUND CONSTRUCTION AND SURVIVAL - HUMID CONDITIONS.............. 24

WESTERN UNITED STATES PREHISTORIC MOUNDS - GATLIN SITE............... 29

MOUND CONSTRUCTION AND SURVIVAL IN SEMI-ARID CLIMATES............ 29

REFERENCES.............................................. 31 


\section{FIGURES}

1 Basic Components of an Above-Grade Impoundment Design........... 5

2 Basic Components of an Above-Grade Earth Dam Impoundment.......... 6

3 Reconstruction of Fussell's Lodge $=\ldots \ldots \ldots \ldots \ldots \ldots \ldots \ldots \ldots \ldots \ldots \ldots \ldots$

4 A Restored Section of the Fussell's Lodge Long Barrow............ 11

5 Silbury Hill Construction.............................. 13

6 Cross-Section of Pazyryk.................................. 15

7 Section Through the Mound at Gordion, Showing Tomb Chamber, Tunnel, and 0 pen Trench................................. 16

8 The Poverty Point Mound Group............................. 20

9 Schematic Cut-Away Diagram of Typical Conical Burial Mound......... 21

10 The Cahokia Site and Mound Groups.......................... 22

11 Monks Mound at Cahokia.................................... 23

12 The Emerald Temple Mound.................................. 25

13 The Gatlin Mound Profile Showing Six Construction Stages.......... 30 
INTRODUCTION

The long-term protection of uranium mill tailings piles is a serious concern of the uranium mining industry and of government regulatory agencies. The tailings are proposed to be permanently stored in impoundments, either aboveground or below-ground, and covered with a radon suppression cap and earthen cover. Pacific Northwest Laboratory (PNL) is conducting studies, sponsored by the Nuclear Regulatory Commission (NRC), on the mitigation of wind and water erosion of the stabilized tailings impoundments through the use of a rock armoring blanket (riprap) or other methods.

The effectiveness of mitigation techniques depends on a number of environmental and engineering factors, not the least of which is the structural stability of the tailings impoundments themselves. Because impoundments will be subjected to natural erosional and weathering forces for long time periods, we investigated archaeological records to discover if ancient man-made earthen structures have survived on time scales comparable to the expected service lives of uranium tailings impoundments.

This document discusses the survivability of prehistoric man-made earthen and rock structures and looks at specific examples. Where such information is available, the influence of construction techniques, materials, and climate on the ancient structures is discussed.

In the following sections, examples of mound construction from Europe, Africa, and the Near East; from the eastern United States; and from the western United States are given. A Conclusions and Recommendations section summarizes the findings and relates them to the long-term survivability of uranium tailings impoundments. 


\section{CONCLUSIONS AND RECOMMENDATIONS}

Man has been building earthen mounds throughout the world for several millenia. Generally, the mound sites represent population and cultural centers and are located near rivers, lakes, or coastlines. Many of the mounds that have been surveyed and documented are burial or entombment sites. Other major types of mounds studied are platform mounds, which may contain several million cubic feet of earth; effigy mounds, which resemble human or animal forms; and midden mounds, which are trash heaps.

In this report we discuss examples of earthen/rock mounds from around the world that have survived natural erosional forces on time scales comparable to the anticipated life expectancies of uranium tailings impoundments. The evidence of the survival of large prehistoric man-made earthen structures indicates that tailings impoundments can remain suitably sound for a very long time. However, the lack of hard data on soil charcteristics, porosity, permeability, compaction, and so forth, restricts us from making quantitative comparisons between the characteristics of tailings impoundments and those of ancient earthen mounds. Also, we cannot discuss in detail the engineering properties that have contributed to the survival of ancient mounds because few such studies have been conducted. However, evidence in the archaeological record suggests that large man-made earthen structures can remain sound and intact for time periods comparable to those required for the stabilization of uranium tailings impoundments. For improved mound stability the following design features and location conditions should be either avoided or protected against:

- the use of retaining walls (timber or other materials) to maintain side slopes to reduce the earthen material requirement.

- the use of steep slopes such as $1 \mathrm{~V}: 2 \mathrm{H}$ that lead to slope failures (slumping) unless the interior design of the embankment can provide the necessary slope stability.

- the lack of rock covering (armoring), especially in semi-arid climates where long dry spells prevent the establishment of vegetation but where local rainfalls are intense

- flood plain locations where river migration (bankline erosion) is imminent

- the use of brick or brick-like materials for the construction of walls or embankments that cannot tolerate any settlement or lateral movement

- the use of materials that attract rodents because rodents dig burrows and displace cover material

- conditions conducive to the establishment of large trees (mainly eastern United States)

- the use of mound configurations (such as pyramids) that provide sharp, well-defined corners which are subject to local flood scour. 
The design features and construction methods of the more stable mounds are listed below:

- the use of protective rock cover to protect against erosion and maintain a soil moisture content

- layered and compacted construction of the earthen covers

- the use of staged construction where each stage is stabilized before others are added

- designs that use interior stabilization such as radial and concentric circular walls

- the use of terraced embankments for slope stability and the provision of solid foundations for each successive stage (multiple levels)

- the use of a stable foundation such as bedrock or an excavated and compacted foundation

- the use of established vegetation where climate permits (eastern United States)

- the opportunity for an initial maintenance period and design flexibility to mitigate instabilities. This would coincide with staged construction. Long construction and occupation periods were advantageous for archaeological mounds because they allowed for maintenance and design revision.

Additional comments regarding the stability of archaeological mounds are as follows:

- Results from semi-arid regions and some slightly humid regions do not indicate any disruption from tree growt:h. Disruptive tree growth seems to occur in extremely wet climates.

- Windblown deposits within the rock covers were not in evidence.

- Embankment slump failures seem to be predominant in the more humid climates (eastern United States) and sheet erosion is more common in the more arid climates. The wetter climates support vegetation which would effectively prevent serious overland erosion, but excessive soil moisture combined with steep side slopes could easily result in slumping.

- Clay caps have proved very beneficial for insuring the stability of mounds in wet climates where they act as a barrier to water infiltration (eastern United States only). 


\section{COMPONENTS OF URANIUM TAILINGS IMPOUNDMENTS}

Above-grade impoundments are analogous to ancient earthen mounds in that they are constructed of earthen embankments, are sometimes protected by rock cover, are similar in size in many cases, and are subject to the same erosional processes. Above-grade uranium tailings impoundments are constructed as roughly four-sided structures (as much as $100 \mathrm{ft}$ in height) in relatively flat areas or can be formed by constructing an earthen dam in an existing watershed. A discussion of the basic construction methods and materials of abovegrade impoundments is presented in this section so that a relevant comparison can be made with the construction practices used in ancient mounds.

\section{CONSTRUCTION METHODS}

Impoundments may be constructed with or without subsurface preparation. Subsurface preparation, such as compaction, would normally be used to prevent seepage from contaminating the ground-water system and wetting the deeper soil horizons. If the undisturbed ground surface is the interface between the tailings and subsurface soils, seepage would mostly be unrestricted and settlement could be a problem. Compaction of the surface soils would reduce seepage from the tailings by decreasing the permeability, but only to a very shallow depth. clay liners are sometimes used as a seal over the compacted earth foundation. The clay liner, if also compacted, forms a nearly impervious layer that would further inhibit seepage from the tailings.

A typical construction sequence for an above-grade impoundment could be described as shown in Figure 1; after compaction of subsoils and the clay liner, an earthen embankment would be constructed on the four sides of the impoundment. The embankment would most likely be constructed of compacted layers of earth. Tailings would then be moved from the mill to the impoundment by a slurry pipeline and diversion ditches, drains, and dikes would be placed as required. As the tailings beach area becomes dry, the surface would be covered with a layer of soil several meters thick which may or may not be compacted. The soil layer could then be covered with topsoil and stabilized with vegetation or covered with rock riprap to prevent any significant wind and water erosion.

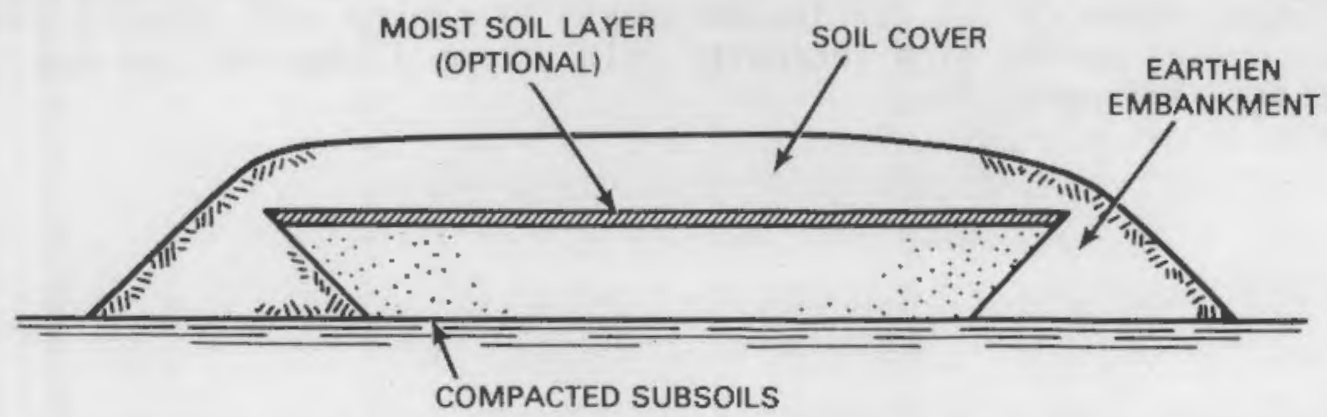

FIGURE 1. Basic Components of an Above-Grade Impoundment Design (adapted from NRC 1980) 


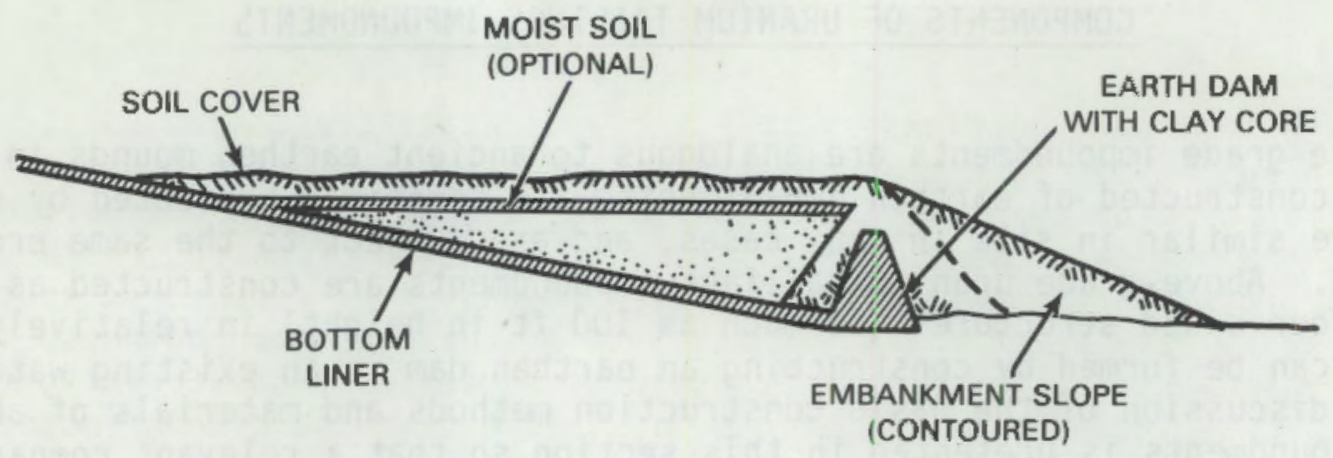

FIGURE 2. Basic Components of an Above-Grade Earth Dam Impoundment

Tailings impoundment dams would be constructed in a similar manner except that topographic features of the watershed would be utilized to reduce the length of embankment (Figure 2). The impoundment dam would be constructed according to accepted geotechnical engineering practices which would include a clay core within the dam to restrict seepage and promote stability.

Actual impoundment construction practices may vary considerable from the above descriptions, especially in the emplacement of the embankments or dams. However, the essential geometry and relative positions of tailings, embankments, and covers shown in Figures 1 and 2 are sufficient representations for the purpose of this report.

SOIL COVERS

Soil covers are used to prevent erosion of the tailings and to reduce the exhalation of radon. The cover material commonly used on tailings impoundments usually contains a significant percentage of clay. Clay tends to hold moisture much better than other soils because of the interactive forces between water molecules and the clay particles. Moisture in the soil cover is desirable because radon attenuation is primarily a function of moisture content.

There are potential problems with the use of cover materials high in clay content. Clays tend to swell when wetted and shrink and crack (dessicate) when drying. Freeze-thaw cycles can loosen crumbs of clayey soil leaving them free to be transported during high intensity rain storms along with the easily transportable fine particles. 
In the following sections examples of ancient earthen mound construction are presented. Sites have been chosen that are similar in their basic construction to uranium tailings impoundments for discussion and evaluation. The mounds at the selected sites are primarily constructed of earth, earthen materials, and rock. The structures are either roughly four-sided or rounded in most cases and have heights similar to those of tailings impoundments. The discussion presents details on the construction methods and materials, that based on archaeological investigations, are believed to have contributed to stability, erosion, or failure of mounds. 



\section{ANCIENT MOUNDS IN EUROPE, AFRICA, AND THE NEAR EAST}

Some of the worlds oldest mounds and rock monuments are found in Europe, Africa, and the Near East. Although numerous sites have been destroyed by human activity, many spectacular sites do remain today. Reported archaeological investigations at several sites provide details on their construction and materials. At a few sites, the eventual structural failures and the reduction of mound height by erosion is documented. Prominent examples of prehistoric mound architecture, their methods of construction, materials used, and survivability are presented in this section.

\section{EUROPEAN MOUND CONSTRUCTION}

Most of the European sites are located in areas bordering the Atlantic Ocean and the North Sea and date from the Neolithic Period or earlier, making them 3000 to 6000 years old (Renfrew 1973). Various terms are used to characterize these structures--mounds, long and oval barrows, tumuli, passage gallery graves, cairns, dolmens, monuments, fortifications--based on the construction materials, configuration, and assumed use.

\section{Burial Mounds-Poland}

The Kujavian graves are ancient, pre-megalithic, unchambered earthen mounds, found in northwestern Poland between the Vistula and Middle Warta rivers. Some Kujavian graves have been radiocarbon-dated at about 5600 years old (Jazdzewski 1973). The structures are long earthen mounds similar in plan to an equilateral triangle where one end is much broader than the other. The mounds often have slightly concave sides. The average length of these mounds ranges from 50 to $100 \mathrm{~m}$ (164 to $328 \mathrm{ft}$ ). They average from 7 to $10 \mathrm{~m}$ (23 to 33 $\mathrm{ft}$ ) wide at the broad end and about $1.5 \mathrm{~m}$ (5 ft) high.

Construction materials were obtained from two flanking quarry ditches of trough-like cross-section. Jazdzewski determined the original mound height at about 3 to $4 \mathrm{~m}$ ( 10 to $13 \mathrm{ft}$ ) at the broad end and about 1 to $1.5 \mathrm{~m}$ ( 3 to $5 \mathrm{ft}$ ) high at the narrow end by adding the present-day amount of filled volume of the ditches to the mound volume. The mounds were also surrounded by large erratic boulders, following the shape of the barrow. The boulders may have been used to stabilize and protect the mound but Jazdzewski does not indicate this in the report nor does he indicate the height of the boulder structure.

The above estimates indicate that the Kujavian mounds were reduced to less than half of their original height by erosional processes. The present height is about $1.5 \mathrm{~m}$ compared to an original height of about 3 to $4 \mathrm{~m}$, indicating a height reduction of from 1.5 to $2.5 \mathrm{~m}$ ( 5 to $8 \mathrm{ft}$ ). Considering a 5600 year period an average erosion rate per 1000 years would vary from about 0.9 to $1.5 \mathrm{ft}$. However, soil losses most likely occurred very rapidly at first, and therefore, the initial 1000 years could have easily accounted for most of the height reduction due to erosional processes. 
Many ancient mound structures remain in the British Isles today in various conditions. Estimates of the ages of these mounds range from about 3500 to over 5000 years. Some mounds, such as Silbury Hill (de M. Vatcher and Vatcher 1976) are in an excellent state of preservation. Others such as Fussell's Lodge (Ashbee 1970) encountered structural failures which allowed significant erosion to occur.

\section{Fussel1's Lodge}

Fussell's Lodge is one of the older mounds in England and has been radiocarbon-dated at 3230 B.C., $\$ 60$ years. It is located on the plains of Salisbury, approximately 7 miles from the Stonehenge cluster arid is considered part of the Salisbury Plains East Group of long mounds. Figure 3 is a reconstruction of the structure based on findings during a 1957 excavation (Ashbee 1970).

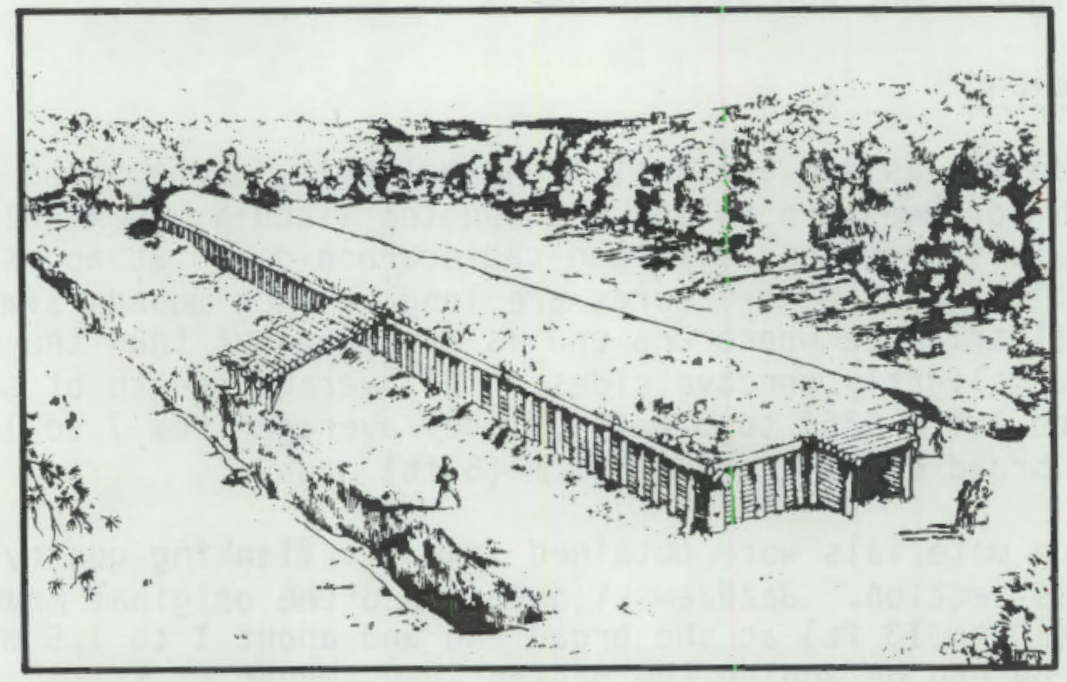

FIGURE 3. Reconstruction of Fussell's Lodge

As constructed, the mound was a timber-enclosed, trapezoidal mound of chalk and earth $135 \mathrm{ft}$ lang, $20 \mathrm{ft}$ wide at the distal end, $40 \mathrm{ft}$ wide at the proximal end, and $8 \mathrm{ft}$ high. An estimated $28,000 \mathrm{ft}^{3}$ of chalk was obtained from flanking ditches extending the length of the mound on each side. An A-frame, timbered mortuary house, about $25 \mathrm{ft}$ long by $15 \mathrm{ft}$ wide, was enclosed at the proximal end.

Figure 4 is a cross-section through the mound as it was found during the excavation. The mound is $170 \mathrm{ft}$ long by $47 \mathrm{ft}$ wide by $3.3 \mathrm{ft} \mathrm{high}$. The slope 


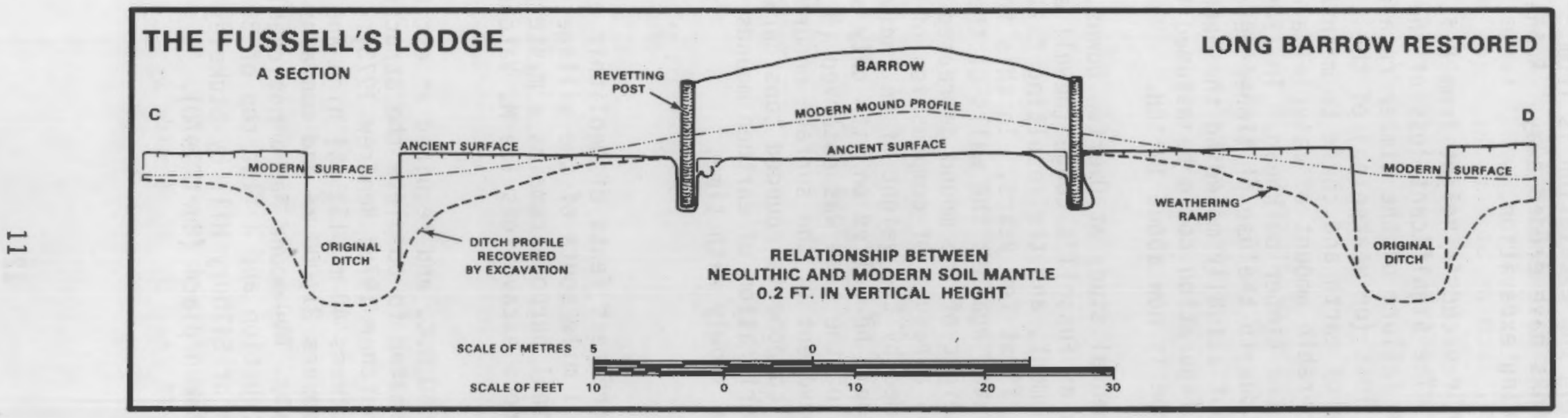

FIGURE 4. A Restored Section of the Fussell's Lodge Long Barrow 
angle of the earth found during the excavation is from $5^{\circ}$ to $10^{\circ}$. Both ditches have been filled and their banks have eroded away. Remnants of the timber mortuary house were found during excavation.

Fussell's Lodge has been reduced in height from $8 \mathrm{ft}$ to a present height of $3.3 \mathrm{ft}$ since constructed. The significant loss of the earth and chalk rubble occurred following the failure of the timber retaining wall. This is not too surprising since any loss (or weakening) of the timber retaining walls would leave the vertical face of earth and chalk to maintain its own stability, which it could not. A considerable amount of material along the perimeter would have failed along with the timber bulkhead. The loss of more than half the mound height is probably due to the use of timber retaining walls to reach a certain height ( $8 \mathrm{ft}$ ) without actually mounding the material to some stable slope. The present slope configuration could be assumed to represent stable conditions where the side slope is now about $1 \mathrm{~V}: 10 \mathrm{H}$.

A modern ongoing experimental study at Overton Downs, England, on toss and heap chalk rubble mounds such as Fussell's Lodge (Jewell and Dimbleby 1977) indicates that erosion, settlement, and the resulting filling of side ditches progresses rapidly during the first few years. In this instance, as much as 36 inches of material accumulated against the walls of the ditch in 4 years and both edges had failed. The height of the mound decreased noticeably

(6-1/2 in.) almost entirely as a result of compression of the core. Initially, the surface was readily deformed by the weight of an individual; however, within 21 months, the slope could be walked on with only a slight distortion of the surface. Some broadening of the base was observed ( $9 \mathrm{in}$. in $25-1 / 2$ months) and a 4-to-7-inch downslope movement of the surface occurred. In the four-year time period, the edges of all components rounded considerably. This study suggests that the rate of deterioration of earthen mounds is most rapid early in their lifetimes, decreasing slowly with time.

\section{Silbury Hill}

Described as one of the greatest feats of Neolithic engineering, Silbury $\mathrm{Hill}$ is located approximately $1 \mathrm{mile}$ south of the village of Avebury in north Wiltshire, England. Its original purpose remains a mystery, but much is known of its construction from numerous excavations (de M. Vatcher and Vatcher 1976; Burl 1970; Renfrew 1973).

The mound was begun in $266 \mathrm{D} \mathrm{B.C.} \mathrm{and} \mathrm{required} \mathrm{an} \mathrm{estimated} 18$ million manhours to build. The time estimated to complete the structure ranges from 10 to 150 years (de M. Vatcher and Vatcher 1976; Renfrew 1973). It is the largest man-made mound in Europe and stands $40 \mathrm{~m}(131 \mathrm{ft})$ high and has a base diameter of $165 \mathrm{~m}(541 \mathrm{ft})$. The hill covers $21,000 \mathrm{~m}^{2}$ and contains approximately $250,000 \mathrm{~m}^{3}$ of quarried material. The mound has a noticeable terrace around the next to last step in its construction and a flat top of $30 \mathrm{~m}^{2}$. A comparison of photos with a from 1725 sketch of Silbury Hill by Stukeley indicates that little erosion or change has taken place (Burl 1970). 
The mound was built in stages. The primary mound was made up of a series of complex layers of river and flood-plain gravel and local turf. It has a diameter of $165 \mathrm{~m}(541 \mathrm{ft})$ was $5 \mathrm{~m} \mathrm{high,} \mathrm{(16} \mathrm{ft),} \mathrm{and} \mathrm{was} \mathrm{constructed} \mathrm{on} \mathrm{a}$ natural chalk promontory, which added an average $9 \mathrm{~m}$ (30 ft) to the mound's height. The promontory was eventually shaped into a conical foundation with steep side slopes.

During the next two stages, the mound was systematically built-up in concentric rings filled with chalk. Figure 5 is a drawing of the construction technique. Six terraces, each about 4 to $5 \mathrm{~m}$ (13 to $16 \mathrm{ft}$ ) high, form large circular drums of quarried chalk. Each drum is composed of several concentric rings and radial spacers, giving it the appearance of a series of cells. The drums decrease in size as the mound increases in height. The outer wall at each terrace, or step, leans inward at an angle of approximately $60 \%$. The cells were filled with chalk rubble and were compacted before the next course of chalk blocks were added with a slight offset inward. At some point in the construction, the builders decided to increase the height of the mound and fill the quarry ditch. A second quarry ditch, which is still discernible, was opened; the old ditch was buried under the present mound. The ditch surrounding the hill, now filled with silt, was originally $38 \mathrm{~m}(125 \mathrm{ft})$ wide and $9 \mathrm{~m}$ (30 ft) deep, with a rectangular extension running toward the west. The inner side of the ditch was built up with chalk and was held in place with riveted timber steps, apparently as protection for the base of the hill.

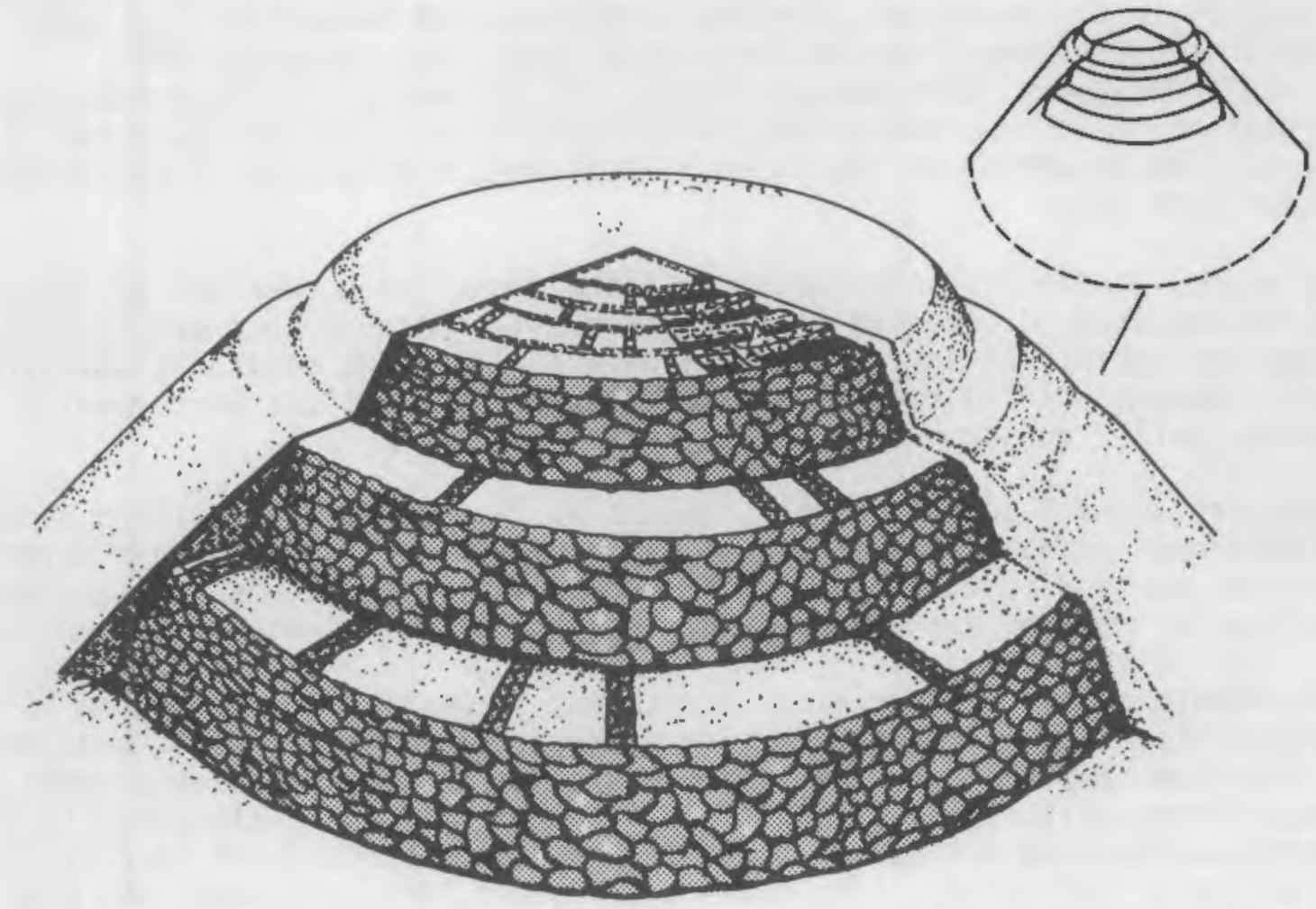

FIGURE 5. Silbury Hill Construction (from de M. Vatcher and Vatcher 1976) 
The final step involved filling in all the large chalk platforms except the top one. This produced a well-defined terrace some 4 meters ( $13 \mathrm{ft}$ ) from the flat top. The basic material of construction used for Silbury $\mathrm{Hill}$ is the same as that used in Fussell's Lodge, but the construction method provided better durability.

Silbury Hill has demonstrated excellent durability for a mound constructed about 4600 years ago. The mound was constructed on a chalk-bed foundation which would provide stability with respect to foundation settlement. Both exterior and interior design features have contributed to its stability. The interior was divided into compartments by radial and concentric circular walls. The stability of the exterior earthen cover is probably partly due to the concentric wall design that provided terraces of durable and stable materials which provided a sound base for the earth cover. Based on the reported circumference of the base and the height dimensions of the mound, the side slopes were approximately $1 \mathrm{H}: 2 \mathrm{~V}$ which is an extremely steep slope to maintain for several thousand years.

\section{RUSSIAN STEPPES/TRANSCAUCASUS}

Thousands, and perhaps hundreds of thousands, of mounds (called kurgans by the Russians) stretch from the fringes of the Balkans (Bessarabia, eastern Germany, and Hungary) to the Altai Mountains on the fringe of Mongolia (Rice 1957; Rudenko 1970; Sulimirski 1970; Trippett 1974). Most authorities attribute the mounds to the Scythians, kindred Scythians, and Sarmatians who dominated the area during the first millenia B.C. (Rice 1957; Rudenko 1970;

Trippett 1974; McGovern 1939; Sheratt 1980); but Sulimirski (1970) points out the association of earthen mounds and fortifications with earlier cultures in the region. The beginning of burial mound building in this area is estimated to be about 1200 B.C.

The mounds in the Altai Mountains near the Mongolian border are of special interest to the study of uranium mill tailings piles because they are covered with stone and exhibit phenomena that may have implications regarding moisture retention. Rudenko (1970) reports on the extensive excavations performed in this region, mainly on the mounds at Pazyryk.

There are 40 rock-covered, frozen mounds at Pazyryk on the southern slope of the Chulyshman range within a mile of the valley of the Great Ulagan River. This area has exposed rock outcrops, heaps of broken rock fragments talus, and numerous glacial moraines, all providing necessary building materials.

The climate of the eastern Altai Mountains, in particular the region of the Pazyryk Site; is characterized by low average annual temperatures and long winters with low temperatures. Minimal cloud cover in winter causes a great heat loss, strong chilling, and deep freezing of the ground. Calm conditions predominate during cold periods of the year, producing temperature inversions and refreezing of the valley. The summers are short, dry, and cool, and are characterized by high midday temperatures and cold nights. Although all the 
climatic conditions for the formation of permafrost are present, the region does not have permanently frozen ground because mean annual temperatures are not low enough and surface conditions are variable.

Five of the mounds are larger than the rest and all have the same basic structure. Figure 6 is the cross-section for one of the mounds (Rudenko 1970). The mound is between 40 and $46 \mathrm{~m} \mathrm{(131} \mathrm{and} 151 \mathrm{ft}$ ) in diameter. The tomb shaft is about 51 to $55 \mathrm{~m}^{2}$ and extends $4 \mathrm{~m}(13 \mathrm{ft})$ below grade. In this mound, three layers of logs were placed over the tomb, covered by a bed of 60 boulders, plus 2 boulders (each weighing approximately 3 tons) over the horse burials. The rock bed was covered by five tiers of logs (approximately 30 logs per tier), and then covered by an earthen mound containing boulders, also weighing up to 3 tons each. The earthen mound was paved with angular stones (predominantly red, tuffaceous sandstone). The cairn consisted of larger rocks, and pebbles and gravel which filled the spaces between the large stones. A ring of flat upright boulders at intervals of from 3.5 to $5.7 \mathrm{~m}$ (11 to $19 \mathrm{ft}$ ) encircles the periphery of the cairn. Looters in ancient times bored a hole into the tomb and threw all stones in a 10 to $15 \mathrm{~m}$ ( 33 to $49 \mathrm{ft}$ ) diameter out toward the edge.

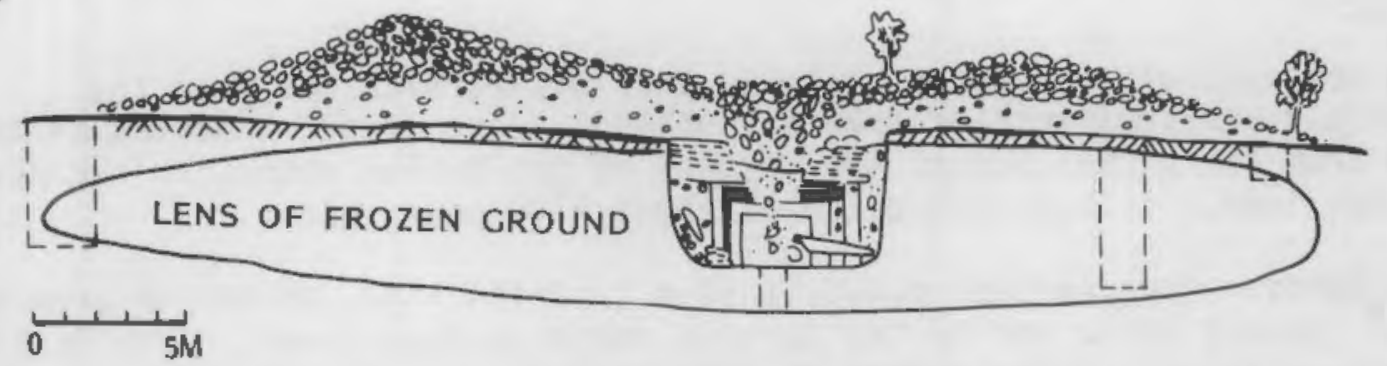

FIGURE 6. Cross-Section of Pazyryk (Rudenko 1970)

Lenses of frozen soil were found during the excavation of all these mounds. In early summer the frozen layer began at the surface, but receded 0.4 to $0.5 \mathrm{~m}(\sim 1.5 \mathrm{ft})$ by late summer. In most cases, the frozen layer extended to the bottom of the shaft, approximately $1.5 \mathrm{~m}(5 \mathrm{ft})$ lower. The edges of the frozen soil lenses did not extend beyond the rock cover. The thickness of the layer diminished somewhat in the center because of the looter's crater, and reached its maximum thickness under the inner ring of stones thrown up by the looters. Formation of the frozen soil lens began before the looting.

The implication that applying a rock cover may lead to the formation of a permanently frozen layer under certain conditions may be significant for tailings impoundments. Such a layer would substantially increase the stability of the mounds, and increase radon attenuation.

Rudenko (1970) attributed the frozen layer in the mounds mainly to the cairn of stones. The cairn insulated the underlying earth from the summer heat and this delayed the thaw. Under winter conditions the stone releases heat more rapidly than does the ground surface. Because the cairn is a poor heat conductor, large, absolute changes in the daily and annual temperature sequences 
were prevented and the extremes softened. Rain was allowed to infiltrate through the rock, during the warm time of the year the rock delayed evaporation, condensed the moisture, and increased the overall dampness of the ground. Finally, the cairn acted as a light shield which reduced the penetration of light. Thus, climate combined with peculiarities of mound and cairn construction to produce a temperature equilibrium under the cairn and a lens of frozen ground.

These burial mounds have been damaged by looting, but no other structural damage or erosion is apparent. The apparent reason for the mounds durability is the permanently frozen earth under the rock cairn. The mounded earth remains frozen primarily due to mound and tomb design. The stability resulting from permanently frozen ground may or may not be significant for uranium tailings impoundments in the continental United States. Not enough information is available regarding seasonal ground conditions at the various sites. These impoundments are located in areas that do not experience deep freezing of the ground during winter. Two key points here seem to be: that the stone does not appear to have appreciably weathered over the 2500 year period, and that the rock protection decreased evaporation and increased soil moisture.

ASIA MINOR

The remnants of the ancient city of Gordion are situated near the Sanquarious River southwest of Ankara, Turkey. Young (1958) reported on the findings from the excavation of the largest of the burial mounds in the area, the Gordion Tomb. It has been dated at about 2700 years old.

The Gordion Tomb earthen mound is $50 \mathrm{~m}$ (164 ft) high, covers an area of $50,000 \mathrm{~m}^{2}\left(59,802 \mathrm{yd}^{2}\right)$, and is the largest mound in Asia Minor. Clay is the structural material. Its diameter is estimated at approximately $270 \mathrm{~m}$ (886 ft) making it considerably larger than Silbury Hill in England or the Big Barrows in Russia. Figure 7 is a drawing of a cross-section through the mound.

Excavators discovered that the initial $3 \mathrm{~m}(10 \mathrm{ft})$ of the radius of the Gordion Tomb are made up of earth that had been displaced from the mound proper. The slope of this material is about $10 \%$. The diameter of the mound, as built, must have been at least 45 to $60 \mathrm{~m}$ (148 to $197 \mathrm{ft}$ ) less, and its height, greater than its present configuration. The slope of the remaining mound is estimated at about $22^{\circ}$.

The Gordion Tomb has experienced severe erosion over its 2700 year life, as evidenced by the large increase in base diameter due to eroded material. The earthen material used was primarily clay. The severe erosion could have been due to a number of causes; however, no structural failures (slumping, settlement, etc.) are mentioned. The accumulation of eroded soil at the base seems to indicate that rainfall-runoff processes caused a gradual erosin of the earthen mound. Part of the problem may be the climate. If the climate of the area is approximately semi-arid it may explain the significant overland erosion that has occurred. Within semi-arid climates an extensive vegetation cover cannot develop and rainfalls are intensive. No information is available in the report on the original height, construction method used, or the climate. 


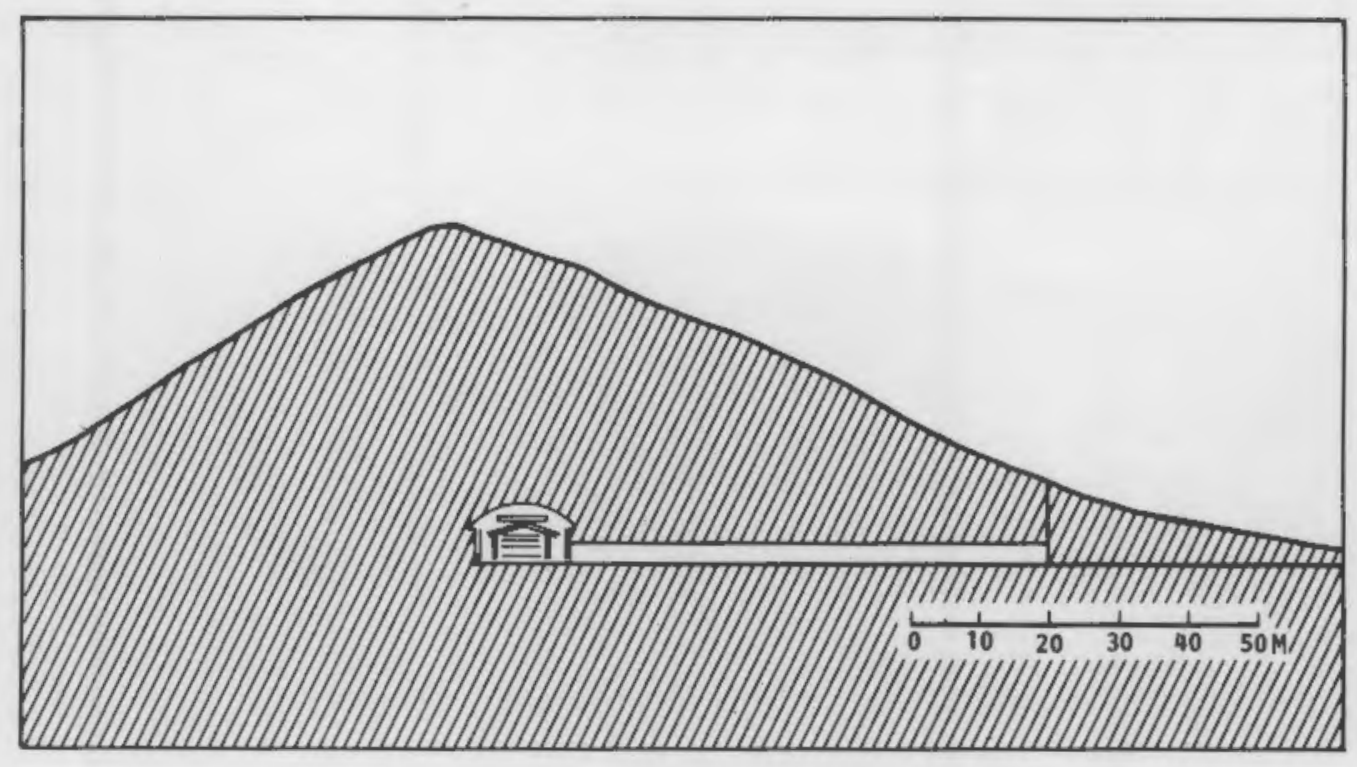

FIGURE 7. Section Through the Mound at Gordion, Showing Tomb Chamber, Tunnel, and Open Trench

NORTH AFRICA

A group of mounds attributed to the Nubian culture (300 B.C. to A.D. 300) are found in the Nile River Valley between the first and second cataracts. These mounds are not well documented. One of these mounds near Ballana was reported to be covered with schist pebbles and the dimensions of another are given as $11.5 \mathrm{~m}$ (38 ft) with a diameter of $76 \mathrm{~m}(249 \mathrm{ft}$ ) (the size of some of the Scythian mounds). The mounds are essentially of a layered construction that has effectively resisted natural erosion. Their unobtrusiveness appears to have protected them from looting. Another feature that may have contributed to their protection is the mud-brick material of construction of the tomb under the mound. When first uncovered, the top of the tomb had the appearance of an unbroken surface of smooth, black soil. Actually, the unbaked mud bricks were fused together by water.

Since the "bricks" of the Nubian mounds were not fired they were probably a well-consolidated earthen material composed primarily of clay. Because of their unbaked condition, they could have retained some flexibility to accommodate minor changes in loading where fired bricks would have fractured. The layered earth mounds appear to have resisted erosion, however, not enough information is available to substantiate this satisfactorily. 


\section{EASTERN AMERICAN PREHISTORIC EARTHWORKS}

Some of the most spectacular examples of earthen architecture, several hundred to several thousands years old, are found in the eastern and central United States. American explorers and settlers, pushing westward along the Mississippi and Ohio River valleys, discovered large earthen mounds that were frequently arrayed to resemble a cultural or ceremonial center of activity. Some of the mounds contained entombments, others seemed to be fortifications or ceremonial platforms. All were overgrown by vegetation, and sometimes the structures first appeared to be natural features of the landscape. Theories concerning the builders of these mounds varied through the years, but as investigations progressed through the end of the 19th century and into the 20th century, ancestors of the native American Indians were recognized as responsible for the thousands of mound sites uncovered in the U.S.

The following sections describe the various periods of mound building in the eastern United States and present examples of the types of mounds found, as well as information on their construction and survivability. The discussion draws heavily from information presented to PNL personnel at a mini-symposium held at the Peabody Museum of Archaeology and Ethnology of Harvard University in January 1982. For additional information on American mounds and the mound builders, the reader can refer to the works of Squier and Davis (1848), an early comprehensive survey of eastern mounds; Haven (1856), a review of American archaeology; Putnam (1890), a survey of the famous Great Serpent effigy mound in Ohio; Thomas $(1889,1891,1894)$, a concise catalog of American mounds; Phillips, Ford and Griffin (1974), a survey of Mississippian settlement patterns; Smith (1978), a review of the Temple Mound tradition; Fowler (1969, 1974), Reed, Bennet and Porter (1968), and Bushnell (1904) for discussions of the Cahokia mound group and Monks Mound; and King (1971) and Silverberg (1968) for overviews of the American mound tradition. For the reader interested in ancient earthen architecture, the book by Morgan (1980) is highly recommended.

EXAMPLES OF MOUND CONSTRUCTION IN THE EASTERN UNITED STATES

The history of earthen-mound building in the eastern half of America spans over 3000 years. The literature describing these sites is extensive; thus, we will cite only a few examples of the largest mounds that are comparable in size to uranium tailings impoundments.

Poverty Point, Louisiana - 1500 B.C. to 1000 B.C.

One of the best examples of the survivability of large earthen mounds occurs at the Poverty Point Site near the Mississippi River in Louisiana. This site is somewhat of an enigma to archaeologists because nothing else of its magnitude was constructed this early in America. Started around 1500 B.C., it predates the Burial Mound periods by several hundred years and existed long before the Temple Mound tradition began. The drawing of the site presented in Figure 8 depicts the site much as it exists today. Note the concentric-ring mounds and the large, conical mounds. This site is over $1500 \mathrm{~m}$ (4900 ft) wide and the diameter of the ring mounds, which are only $2 \mathrm{~m}(6.6 \mathrm{ft}) \mathrm{high}$, is over 

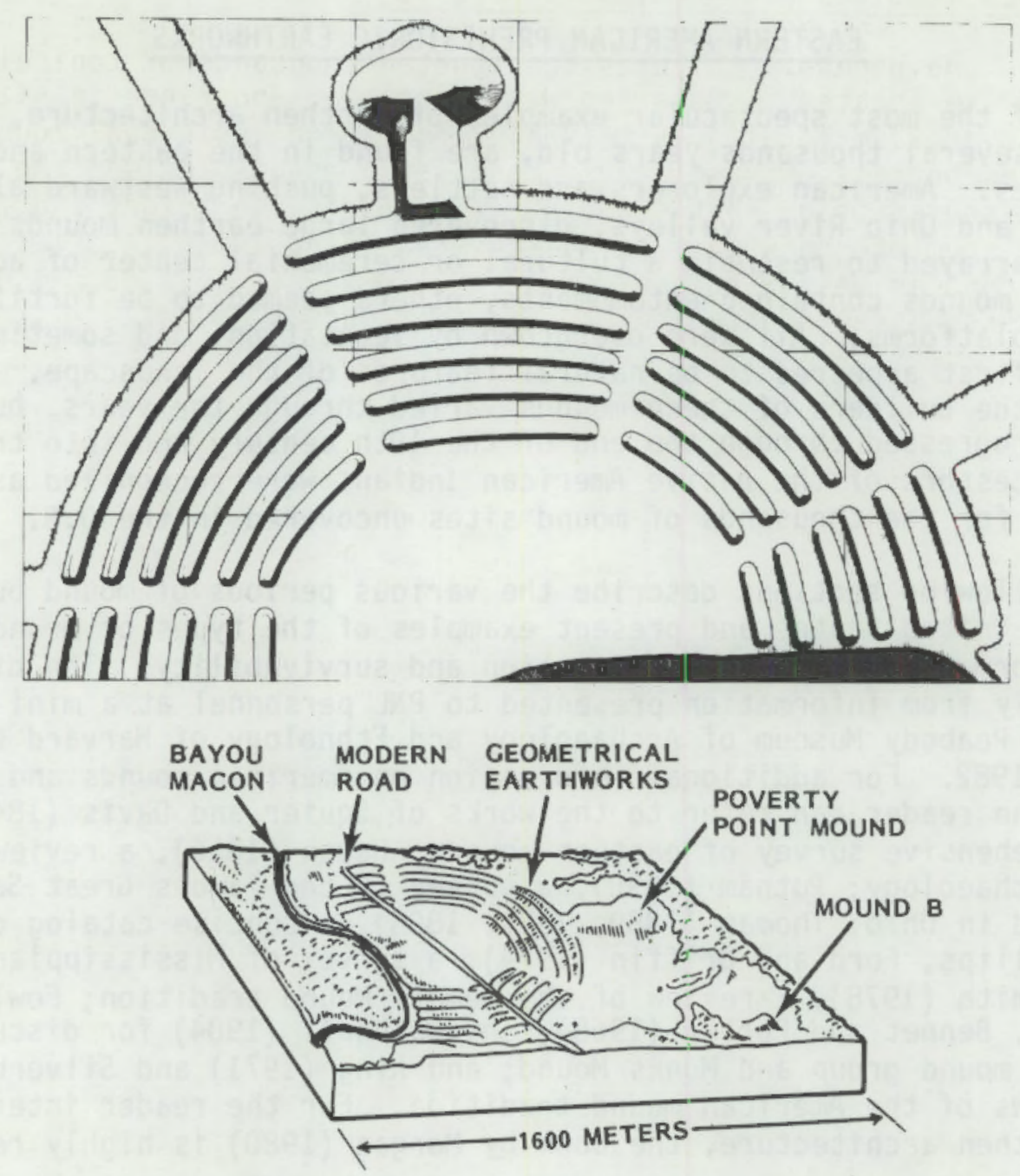

FIGURE 8. The Poverty Point Mound Group (top figure from Morgan 1980; bottom figure from Jennings 1978)

$1200 \mathrm{~m}(4000 \mathrm{ft})$. The small stream shown in the figure changed its course at some earlier time, cutting off and destroying a portion of the ring mounds. The large mound at the site is over $23 \mathrm{~m}(75 \mathrm{ft})$ high with a diameter of over $200 \mathrm{~m}(650 \mathrm{ft})$.

This site is a complex of mounded-earth structures that are reasonably well preserved, except for partial destruction of the ring mound caused by erosion resulting from migration of the river channel. This is the primary problem at this site because overland erosin would be effectively prevented by growth and maintenance of vegetation. There is no information about side slopes of the mounds or the method of construction. River-bankline erosion and migration are particularly damaging because they undermine any structure along the bank. Such processes can cause complete destruction of the site if allowed to persist. 
Adena and Hopewell Sites - 1000 B.C. to A.0. 700

The Adena and Hopewell cultures constructed thousands of conical burial mounds. Most are located in Ohio and West Virginia, and range in size from under $1 \mathrm{~m}$ to over $23 \mathrm{~m}(75 \mathrm{ft})$ in height. Some large individual mounds contain several hundred burials. Examples of these large mounds include the conical mound in Miamisburg, Ohio, that measured $21 \mathrm{~m}(69 \mathrm{ft})$ in height and $260 \mathrm{~m}$ $(850 \mathrm{ft})$ in circumference when first discovered (King 1971). Likewise, the Grave Creek mound in West Virginia measured $22 \mathrm{~m}$ (72 ft) by $305 \mathrm{~m}$ (1000 ft). Figure 9 presents a representation of a typical burial mound.

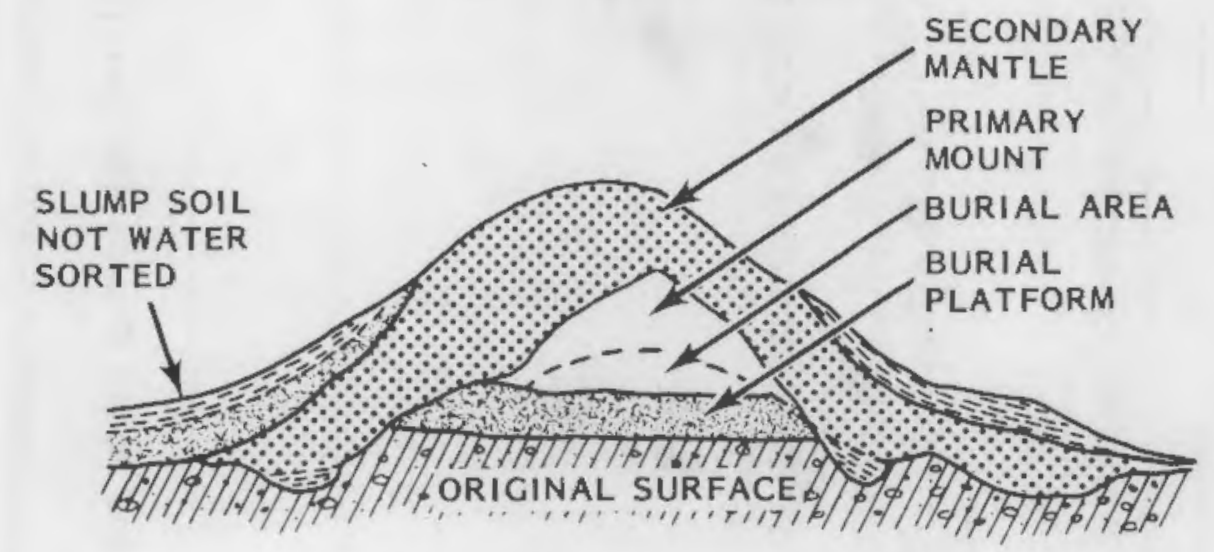

FIGURE 9. Schematic Cut-Away Diagram of a Typical Conical Burial Mound (from Jennings 1978)

Based on the height and circumference of the Graves Creek and Miamisburg mounds, the side slopes would be about $1 \mathrm{~V}: 2 \mathrm{H}$. Slump failures were evidently a common occurrence and could be expected for side slopes this steep. The steep side slopes together with the wet climate of the eastern United States could explain the slump failures which occurred regardless of the layered and compacted earth' construction.

The Mississippian Tradition - A.0. 700 to 1700

The Mississippian culture is responsible for the construction of the great temple mound sites, which are spectacular because of their great size. The best documented of these sites is the Cahokia Site outside of East St. Louis, Illinois (Figure 10). Cahokia covers 3700 acres, or nearly six square miles; originally it contained over 100 mounds. The Cahokia Site was occupied between A.D. 800 and 1550, according to radiocarbon-dating of artifacts found there (Fowler 1969). About 20 of the original mounds were destroyed by agricultural expansion and the growth of East St. Louis and an interstate highway cuts through the site.

The largest mound in North America is Monks Mound at Cahokia (Figure 11). Monks Mound is a terraced, platform structure consisting of four levels built 


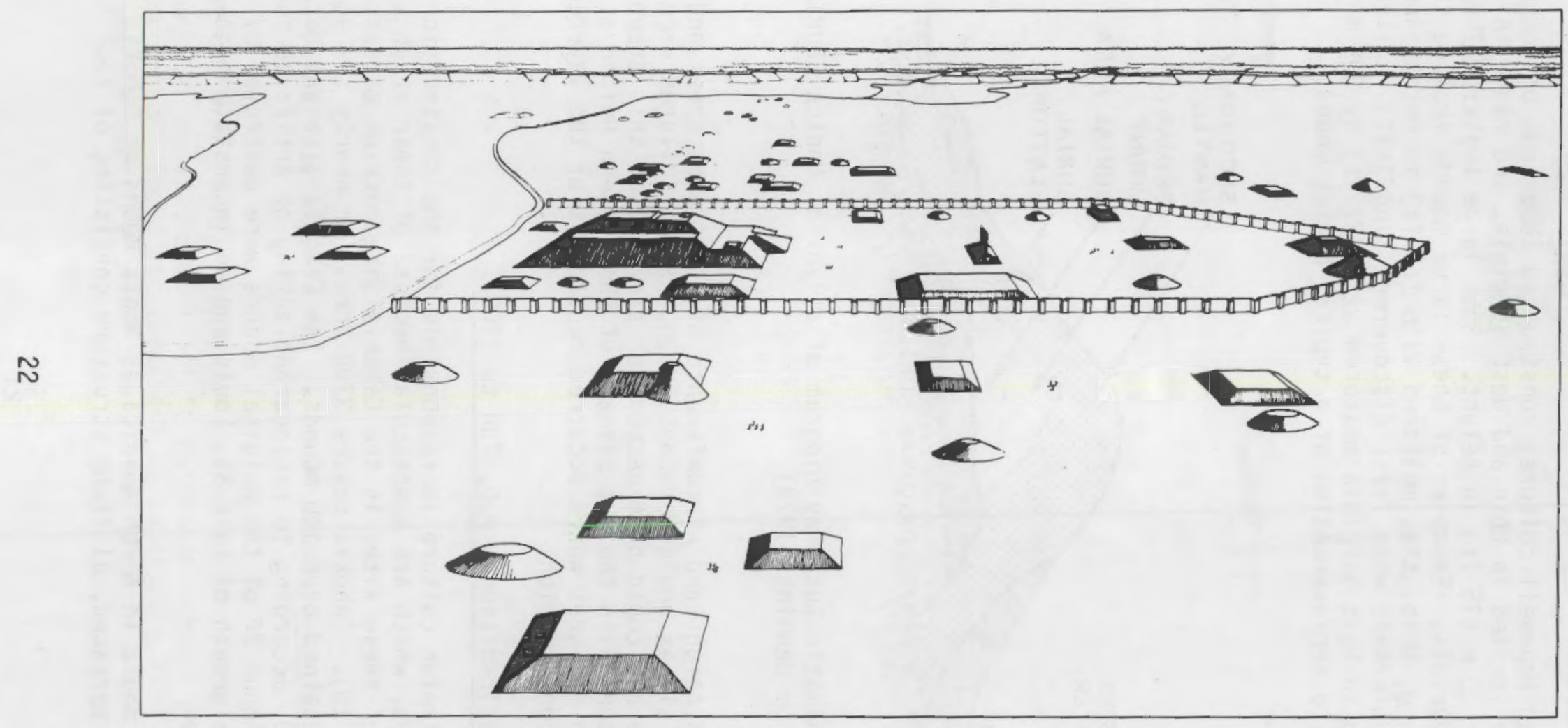

FIGURE 10. The Cahokia Site and Mound Groups (Morgan 1980) 

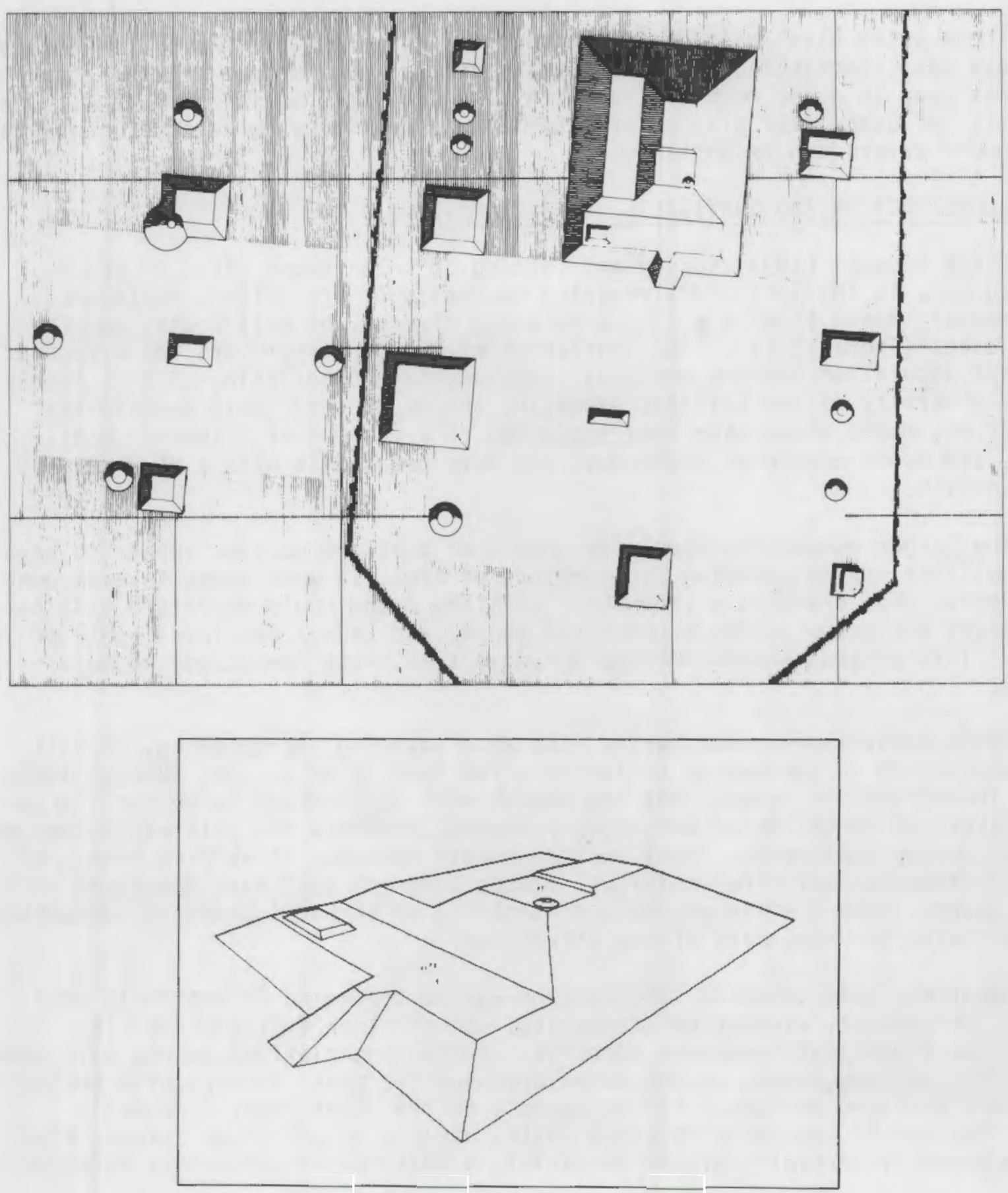

FIGURE 11. Monks Mound at Cahokia (Morgan 1980)

in fourteen stages and contains nearly $600,000 \mathrm{~m}^{3}\left(21 \mathrm{million} \mathrm{ft}^{3}\right)$ of soil (Fowler 1969). The longest dimension of the full structure is about $316 \mathrm{~m}$ $(1050 \mathrm{ft})$. When first discovered in the $1860 \mathrm{~s}$, it stood intact, and although it has been partially destroyed since then, there is little evidence of erosional or catastrophic soil loss. 
These sites have design features such as terracing and staged construction that may have contributed to the stability of the large mounds of the group. clay was used in other mounds along with logs and rocks as reinforcement. The necessity of using $\mathrm{clay}$ plus other materials to reinforce corners may indicate that mound covers can be unstable.

\section{MOUND CONSTRUCTION AND SURVIVAL - HUMID CLIMATES}

Cyrus Thomas' (1891) survey and catalog of known mound sites in the eastern U.S. in the late 1800 s revealed thousands of prehistoric earthworks. Most eastern mound sites are clustered along rivers, the Gulf Coast, and the Great Lakes (Thomas 1891). The confluence of two or more rivers was a popular site for population centers and thus, for numerous mounds (King 1971). Because of the diversity of the cultures producing the mounds and their geographical separation, mound sites have been subjected to a variety of climatic conditions, and hence erosional processes, and have been built with a wide variety of materials.

The larger mounds, particularly temple or platform mounds, appear to have been built in stages spanning long periods of time, in some cases several hundred years. For example, a ceremonial platform mound would be raised to a certain level and occupied for a period of years, and then a new level would be added. This process would continue for some time, with new stages added as needed.

Mound excavations consistently display a layering, or mantling, of soil that was placed in the mounds in layers a few feet thick at most (Morgan 1980). These investigations reveal that the mounds were constructed by workers carrying baskets of earth, which were simply dumped, and then the soil was spread by hand or wooden implements. Many mounds contain numerous stratified lenses of soil, indicating where the individual basket loads of soil were deposited in a given layer. Foot traffic and natural settling of the soil promoted compaction and increased the stability of the structures.

Materials used in mound construction varied depending on available soil types. In general, excavations reveal the use of clean fill such as clay, loess, and flood-plain sediment deposits. Burial and platform mounds have been noted for the homogeneity of the materials used for their construction throughout their building periods. Effigy mounds, on the other hand, frequently reveal the use of specially selected soils, usually of different colors, that were apparently carefully placed to satisfy a cultural or ceremonial purpose.

One interesting aspect of some of the larger temple mounds was the use of a clay mantle for interior reinforcement of the structure. The Emerald site in Mississippi (see Figure 12) is particularly noted for a clay cap covering the entire mound. Apparently, this cap was installed to promote structural stability of the mound. After it was laid and allowed to dry, it became extremely hard; modern excavations have had a difficult time breaking through it. Its placement permitted a steeper side slope of the underlying soil than would 

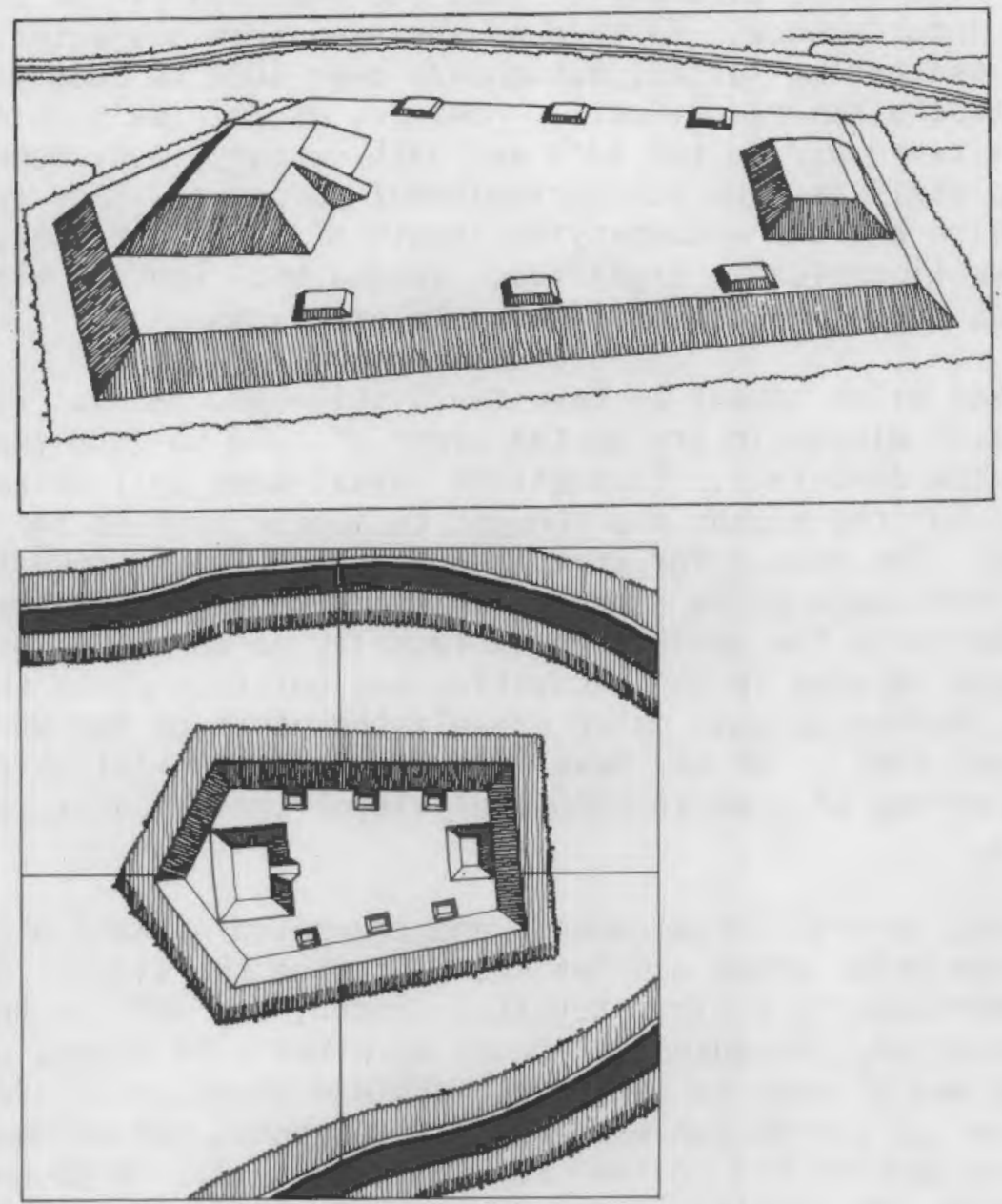

FIGURE 12. The Emerald Temple Mound (Morgan 1980)

normally be expected. 'Gumbo' clay has been found in many other Mississippian mounds, frequently being used to reinforce the corners of temple mounds. Logs and rocks, also used for reinforcement, have been found in excavated mounds.

The use of clays in mound construction had another structural benefit in many cases, although, it is not known whether this benefit was foreseen by the mound builders. Evidence of widespread burnings are found in many earthworks; these burnings fired the clays, providing a brick-like durable layer. In burial mounds, cremations produced this effect which has proved very effective in stabilizing those mounds built in stages. In platform mounds, the burnings may have been of a ceremonial nature or merely for food preparation. Their purpose is not clear, but the effect has been the same: a baked clay cap that has been relatively impervious to water infiltration and erosional processes. 
The rate of survival of American prehistoric earthen mounds has been remarkably high. The mound destruction that has occurred can be attributed largely to man's interference. Earthen mounds have been subjected to a variety of erosional and weathering forces, but mounds over 1000 to 2000 years old have survived these attacks remarkably well. However, as America's European settlers moved westward during the 18th and 19th century, many mounds were partially or completely leveled for agricultural purposes. More recently, industrial expansion and the accompanying growth of urban areas have destroyed thousands of these historically significant landmarks. Looters also, have destroyed numerous sites in search of valuable artifacts.

American mound sites appear to have small soil-loss rates. For instance, the effigy mounds of Wisconsin are on the order of 1200 to 1600 years old, and yet stand only a few feet tall. Excavations reveal some soil movement caused by sheet erosion, but the mounds are thought to appear much as they did when first constructed. The reason for this theory is that these mounds were built with an exact mirror image below grade. The shape to be constructed was first carved into the earth to the desired depth (usually no more than 4 to $6 \mathrm{ft}$ ) and then the soils were layered in the excavation and built up above the surface to the same height. Modern heights match closely the depth of the underlying mirror image (Brown 1982). We may have expected normal soil-loss rates over such an extended period of time to completely level these mounds, but this has not been the case.

The very large conical burial mounds and truncated pyramid platform mounds have survived quite well where man has not disturbed the sites. Several factors probably contribute to their integrity. First, the soil in these structures is very compacted. Because the mounds were built in stages over many years, each stage was allowed to settle and achieve structural integrity before another large layer of overburden was emplaced. Second, the methods of construction may have contributed to the compaction process. Large numbers of workers walking over the mantled layers would gradually pack each layer as it was placed. Third, as already mentioned, the use of clays in many of the mounds had very beneficial results. Lastly, the establishment of vegetation stabilized slopes and reduced the effects of gullying and rill erosion.

Many archaeologists agree that mound slopes were kept free of vegetation during their period of active use. The grasses, shrubs, and trees that cover the sites today did not emerge until the sites had been abandoned. The climates of most of the mound sites in the eastern U.S. are conducive to the rapid growth of vegetation. Thus, a protective layer of grass probably would emerge rapidly on the mounds once they were no longer maintained by the societies that built them. Whereas grasses have provided slope stability and enhanced mound integrity, trees have had the opposite effect. Root action has produced deep crevices in mounds, accompanied by slumping.

Mound excavations revealed that the designers were aware of stability problems. Very early mound sites, several thousand years old, were apparently primitive structures, and most have experienced severe weathering damage. 
These mounds were small and in many cases only potsherds and midden material (trash) remain to prove they once existed. However, mounds from the Burial Mound and Temple Mound periods display a growing awareness of design and construction techniques.

Mound construction became more complex with increasing size, because material placement, angles of repose, reinforcing techniques, and so on were considered. Most mounds are situated along rivers, but partial or complete inundation during flooding does not appear to have seriously affected their stability. Many mounds were placed on locations above the normal flood level at the time of their construction.

Earlier we mentioned the use of clay caps on many mounds as a reinforcing mechanism. These caps were usually placed as the final step in the construction processs. However, these layers provided more than just a hard shell over the mounds; they also served as a barrier to water infiltration into the mound, thus preventing the destructive process of wetting and drying. When soil layers become saturated and subsequently dry out, and if this process is cyclic, the materials alternately expand and contract. This process produces cracks in the layers, allowing more water to penetrate, thereby enhancing the process. This eventually leads to catastrophic failure by slumping and sliding. Such processes have been active in many partially destroyed mounds where no barrier to water infiltration existed. Freezing and thawing of trapped water in the soil produces a similar effect as a result of the expansion of freezing water. The clay caps effectively prevented these processes from destabilizing the mounds. 



\section{WESTERN UNITED STATES PREHISTORIC MOUNDS - GATLIN SITE}

Southern Arizona was the home of another prehistoric cultural tradition, the Hohokam. These people were agriculturalists and lived in shallow pithouses constructed of sun-baker adobe clay or wattle-and-daub; they had little rock available for building. In several instances, these people built low earthen platform mounds.

The desert climate of southern Arizona is hot and dry, with extreme temperature ranges. Annual rainfall is approximately $20 \mathrm{~cm}$ (7 in.) (Haury 1945). Most of the Hohokam settlements were in the Salt and Gila River Valleys. Volcanic mountains of about $800 \mathrm{~m}$ (2625 ft) elevation adjoin these valleys. The Gatlin Site is one of the Hohokam habitations with a prominent mound.

\section{MOUND CONSTRUCTION AND SURVIVAL IN SEMI-ARID CLIMATES}

The Gatlin Site is located above the flood plain of the Gila River. This village was occupied between A.D. 900 and 1100. The Gatlin platform mound measures $29 \mathrm{~m}$ by $22 \mathrm{~m}$ by $3 \mathrm{~m}$ ( $95 \mathrm{ft}$ by $72 \mathrm{ft}$ by $10 \mathrm{ft}$ ) (Willey 1966a; Wasley 1960) and was constructed in six stages of repairs, modifications, and enlargements (Martin and Plog 1973) (Figure 13). In all stages the mound had a flat top with sloping sides and rounded corners, as well as an earthen core; the outline of the mound was rectangular. Each new level was plastered with a mix of caliche and adobe that was from 2 to $10 \mathrm{~cm}(0.7$ to $3.4 \mathrm{in.})$ thick. Some of the fill contained sterile silt and gravel carried in by the basketful. The fill was generally sandy silt with some cultural material, indicating that it had been carried from existing trash mounds. The site had been vandalized before archaeological investigation, so some information was lost (Wasley 1960).

The building sequence for the Gatlin Site mound was as follows. First, the ground surface was covered with caliche plaster. Next, a silty clay was deposited and then clean sand was added until the diameter of the mound was $14 \mathrm{~m}(46 \mathrm{ft})$. Limited remodeling took place at the east and south sides. The cappings of caliche clay were mixed and applied and the resulting surfaces were smoothed. Eight walked-on and capped surfaces were defined. Al though weathering and rodent activity have largely destroyed the mound's original truricatedcone shape, it still stands out as a prominent landmark.

The Gatlin Mound, which was constructed of caliche, adobe, silt, sand, and gravel, experienced significant erosion in spite of a relatively dry climate and layered construction. Instability appears to have been a problem from the beginning as demonstrated by the evidence of remodeling and maintenance. There could have been problems with the adobe and caliche plaster with regard to weathering and erosion. The adobe and caliche may not be durable materials (similar to dried brick) for mound construction. In this case the structure or foundation could have settled causing failure of the caliche plaster cap. The caliche cap was underlain by clean sand, which is a good foundation material only if it can be confined. Rodent activity added to the damage. 


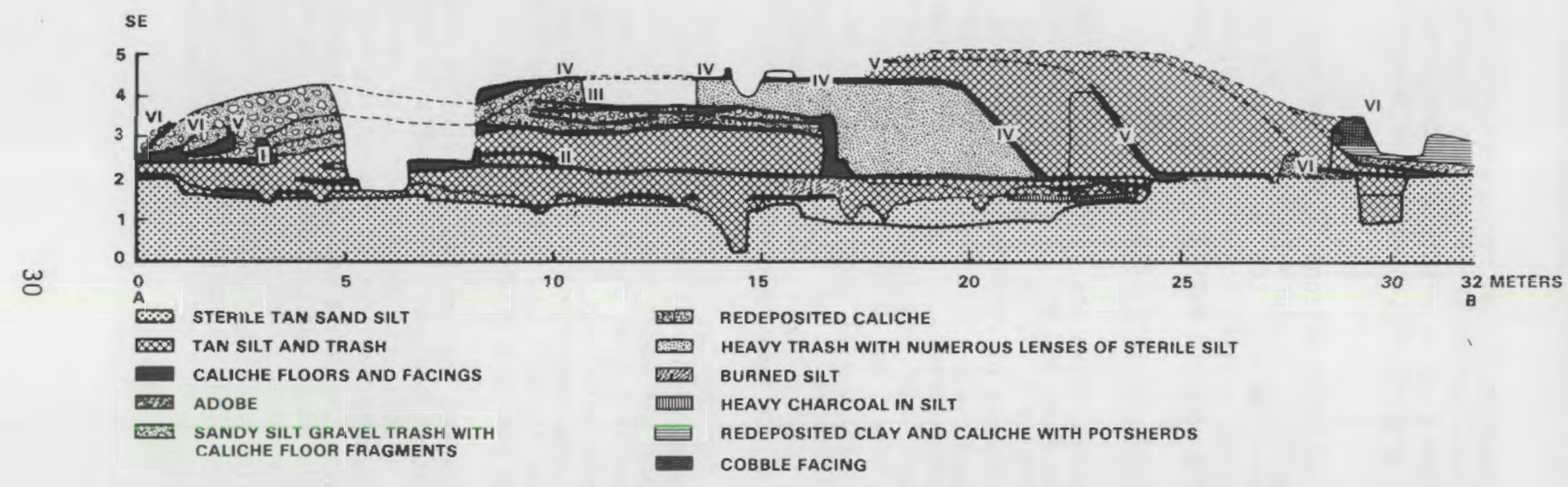

FIGURE 13. The Gatlin Mound Profile Showing Six Construction Stages (Wasley 1960) 


\section{REFERENCES}

Ashbee, P. 1970. The Earthen Long Barrow in Britain. University of Toronto Press, Toronto, Canada.

Burl, A. 1970. Prehistoric Avebury. Yale University Press, New Haven, Connecticut.

Brown, 1. W. 1982. "The Wisconsin Effigy Mound Builders." Paper Prepared for Lower Mississippi Survey, Peabody Museum, Harvard University, Cambridge, Massachusetts.

Bushnel1, 0. 1. 1904. "The Cahokia and Surrounding Mound Groups." Papers of the Peabody Museum of American Archaeology and Ethnology, 3(1), Harvard University, Cambridge, Massachusetts.

de M. Vatcher, F. and L. Vatcher. 1976. The Avebury Monuments, Wilshire, Department of the Environment: Ancient Monuments and Historic Buildings, HMSO, London.

Fowler, M. L. 1969. "Explorations into Cahokia Anchaeology." Illinois Archaeological Survey, Inc. Bulletin No. 7. University of Illinois, Urbana Illinois.

Fowler, M. L. 1974. Cahokia: Ancient Capital of the Midwest. AddisonWesley Publishing Company, Inc. Cummings Pubtishing Company, Menlo Park, California.

Haven, S. F. 1856. "Archaeology of the United States." Smithsonian Contributions to Knowledge VIII, Article II, Smithsonian Institute, Washington, D.C.

Haury, Emil W. 1945. The Excavation of Los Muertos and Neighboring Ruins in the Salt River Valley, Southern Arizona. Papers of the Peabody Museum of American Archaeology and Ethnology, 24(1). Harvard University, Cambridge, Massachusetts.

Jazdzewski, K. 1973. "The Relationship Between Kujavian Barrows in Poland and Megalithic Tombs in Northern Germany, Denmark and Western European Countries." In Megalithic Graves and Rituals, eds. G. Daniel and P. Kjaerum, PP. 63-74, Jutland Archaelogical Society Publication XI.

Jennings, J. D., ed. 1978. Ancient Native Americans. W. H. Freeman and Co., San Francisco, California.

Jewe11, P. A., and G. W. Dimbleby. 1977. "The Experimental Earthwork on Overton Down. Wiltshire, England: The First Four Years." In Experimental Archaeology, eds. D. Ingersoll, J. E. Yellin and W. McDonald, pp. 193-227, Columbia University Press, New York. 
King, B. B. 1971. Under Your Feet. The Story of the American Mound Builders. Books for Libraries Press; Freeport, New York.

Martin, P. S., and F. Plog. 1973. The Archaeology of Arizona. Doubleday/National History Press, Gorden City, New York.

McGovern, W. M. 1939. The Early Empires of Central Asia. The University of North Carolina Press, Chapel HiTा, North Carolina.

Morgan, W. N. 1980. Prehistoric Architecture in the Eastern United States. MIT Press Cambridge, Massachusetts.

Phillips, P., J. A. Ford and J. B. Griffin. 1947. Archaeological Survey in the Lower Mississippi Alluvial Valley. 1940 - 1947. Vol. XXV, Papers of the Peabody Museum of American Archaeology and Ethnology, Harvard University. Cambridge, Massachusetts.

Putnam, F. W. 1890. "The Serpent Mound of Ohio." Century Illustrated Magazine, pp. 871-888.

Reed, N.A., J. W. Bennett and J. W. Porter. 1968. "Solid Core Drillings of Monks Mound: Technique and Findings." American Antiquity 33(2).

Renfrew, C. 1973. "Enigma of the Megalith." In Before Civilization, pp. 120288, Alfred A. Knopf, New York, New York.

Rice, T. T. 1957. The Scythians. Frederick A. Praeger, New York.

Rudenko, S. I. 1970. Frozen Tombs of Siberia, The Pazyryk Burials of Iron Age Horsemen, University of California Press, Berkeley, California.

Sheratt, A. 1980. "The Rise of the Nomads in Central Asia." Chapter 38 in The Cambridge Encyclopedia of Archaeology. V: Empires in the Eastern 0ld World. Crown Publishers, Inc. Cambridge University Press, New York.

Silverberg, R. 1968. Mound Builders of Ancient America: The Archaeology of a Myth. New York Graphic Society, Greenwich, Connecticut.

Smith, B. B., 1978. Mississippian Settlement Patterns. Academic Press Inc., New York.

Squier, E. and E. H. Davis. 1848. "Ancient Monuments of the Mississippi Valley; Comprising the results of the extensive original surveys and explorations." Smithsonian Contributions to Knowledge. No. 1., Washington, D.C. 
Sulimirski, T. 1970. Prehistoric Russia - An Outline. John Baker, Humanities Press, London.

Thomas, C. 1889. Problem of the Ohio Mounds. Bureau of Ethnology, Smithsonian Institute, Washington, D.C.

Thomas, C. 1891. Catalogue of Prehistoric Works East of the Rocky Mountains. Bureau of Ethnology, Smithsonian Institution, Washington, D.C.

Thomas, C. 1894. "Report on the Mound Explorations of the Bureau of

Ethnology. Bureau of Ethnology Annual Report for 1890-1891. 12:1-722.

Smithsonian Insitute, Washington, D.C.

Trippett, F. 1974. The First Horseman. The Emergence of Man Series, Time Life Bcoks, New York.

Wasley, W. W. 1960. "A Hohokam Platform Mound at the Gatlin Site, Gila Bend, Arizona." Amer. Antiquity 26(2):244-262

Willey, Gordon R. 1966. An Introduction to American Archaeology. Volume One: North and Middle America. Prentice-Hall, Inc., Englewood CTiffs, New Jersey.

Young. R. G. 1958. "The Gordion Tomb." Expedition 1(1), University of Pennsylvania Museum Bulletin.

U.S. Nuclear Regulatory Commission (NRC). 1980. Final Generic Environmental Impact Statement on Uranium Milling Project M-25, Summary and Text. Office of Nuclear Material Safety and Safeguards, U.S. Nuclear Regulatory

Commission, Washington DC, September 



\section{DISTRIBUTION}

No. of

Copies

\section{OFFSITE}

U.S. Nuclear Regulatory Commission

Division of Technical

Information and Document Control

20 Frank Swanberg

NRC Office of Nuclear Regulatory Research Washington, OC 20555

3 T. L. Johnson

P. J. Garcia

G. N. Gnugnoli

NRC Office of Nuclear Material Safety and Safeguard

Washington, DC 20555

P. J Magno

M. S. ANR 60

USEPA

401 M. St. SW

Washington, DC 20460
No. of

Copies

ONSITE

50 Pacific Northwest Laboratory

T. J. Bander

L. L. Cadwell

J. M. Doesburg

J. L. Downs-Berg

M. G. Foley (5)

A. F. Gasperino

G. W. Gee

J. N. Hartley

D. R. Kalkwarf

S. E. King (4)

C. G. Lindsey (4)

B. K. Marshall

J. Mishima (4)

I. C. Nelson

R. W. Nelson

G. B. Parker

R. J. Serne

R. L. Skaggs

C. M. Unruh

W. H. Walters (9)

N. J. Wogman

J. K. Young

Publishing Coordination (2)

Technical Information (5) 



\begin{tabular}{|c|c|c|c|}
\hline \multicolumn{2}{|l|}{$\begin{array}{l}\text { NRC FOAM } 335 \text { U.S NUCLEAA REGULATOAY COMMISSION } \\
\text { "11."1" } \\
\text { BIBLIOGRAPHIC DATA SHEET }\end{array}$} & \multicolumn{2}{|c|}{$\begin{array}{l}\text { 1. AEPORT NUMEEA (A SUIONOd ON DOC) } \\
\text { NUREG/CR-3061 } \\
\text { PNL-4541 }\end{array}$} \\
\hline \multicolumn{2}{|l|}{ 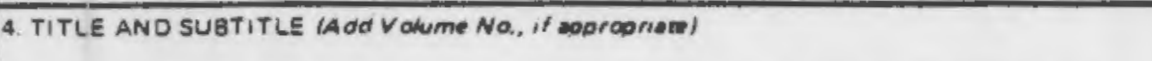 } & \multicolumn{2}{|c|}{ 2. (Leave blenk) } \\
\hline \multicolumn{2}{|c|}{$\begin{array}{l}\text { Survivability of Ancient Man-Made Earthen Mounds: } \\
\text { Implications for Uranium Mill Tailings Impoundments }\end{array}$} & \multicolumn{2}{|c|}{ 3. RECIPIENT'S ACCESSION NO. } \\
\hline \multicolumn{2}{|c|}{$\begin{array}{ll}\text { 7. AUTHQR(S) Lindsey } & \text { S.E. King } \\
\text { J.G. Mishima } & \text { W.H. Walters } \\
\end{array}$} & \multicolumn{2}{|c|}{\begin{tabular}{|l|l|} 
5. DATE REPOAT COMPLETED \\
MONTH & YYAAR \\
Apri & 1983 \\
\end{tabular}} \\
\hline \multirow{3}{*}{\multicolumn{2}{|c|}{ 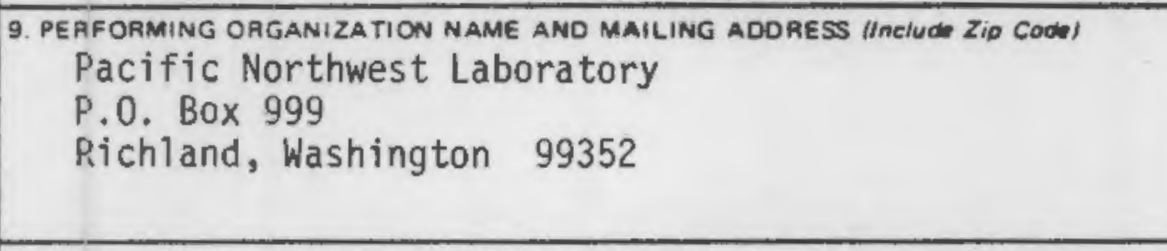 }} & \multirow{2}{*}{\multicolumn{2}{|c|}{ 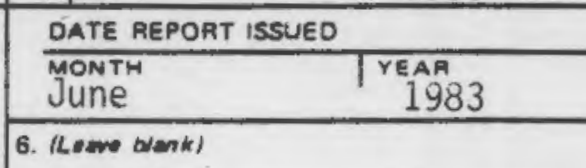 }} \\
\hline & & & \\
\hline & & \multicolumn{2}{|l|}{ 8. (Lembonkt) } \\
\hline \multirow{2}{*}{\multicolumn{2}{|c|}{ 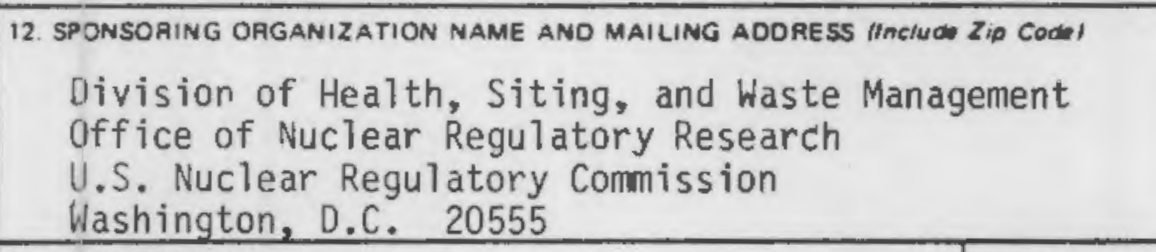 }} & \multicolumn{2}{|c|}{ 10. PAOJECT/TASK/WORK UNIT NO. } \\
\hline & & \multicolumn{2}{|c|}{$\begin{array}{l}\text { 11. FIN NO. } \\
\text { NRC FIN B-2370 }\end{array}$} \\
\hline \multicolumn{4}{|c|}{\begin{tabular}{l|l} 
13. TYPE OF REPORT & PE A1O0 COVEREO Inciusive Gauss \\
Technical &
\end{tabular}} \\
\hline \multicolumn{2}{|l|}{ 15. SUPPLEMENTARY NOTES } & \multicolumn{2}{|l|}{ 14. (Lewe olank) } \\
\hline \multicolumn{4}{|c|}{$\begin{array}{l}\text { 16. ABsThACT Roowors or iess } \\
\text { As part of a study for the Nuclear Regulatory Commission (NRC), the Pacific } \\
\text { Northwest Laboratory ( } P N L \text { ) is investigating long-term stabilization techniques for } \\
\text { uranium mill tailings impoundments. Part of this investigation involves the design } \\
\text { of a rock armoring blanket (riprap) to mitigate wind and water erosion of the } \\
\text { underiying soil cover, which in turn prevents exposure of the tailings to the } \\
\text { environment. However, the need for the armoring blanket, as well as the bianket's } \\
\text { effectiveness, depends on the stability of the unierlying soil cap (radon suppression } \\
\text { cover) and on the tailings themselves. Compelling evidence in archaeological records } \\
\text { suggests that large man-made earthen structures can remain sound and intact for time } \\
\text { periods comparable to those required for the stabilization of the tailings piles if } \\
\text { properly constructed. } \\
\text { In this report, archaeological evidence is presented on the existence ano } \\
\text { survivability of man-made earthen and rock structures through specific exampies of } \\
\text { such structures from around the world. Factors contributing to their survival or } \\
\text { destruction are also reviewed and the influence of climate, building materials, and } \\
\text { construction techniques on survivability is addressed. }\end{array}$} \\
\hline \multicolumn{4}{|c|}{$\begin{array}{l}\text { 17. KEY WOADS AND OOCUMENT ANALYSIS } \\
\text { Uranium Mill Tailings Impoundments } \\
\text { Ancient MOunds } \\
\text { Impoundment Design } \\
\text { Tailings Piles Stabilization } \\
\text { Mound Survivability }\end{array}$} \\
\hline \multicolumn{4}{|l|}{ 176. IDENTIFIERS. OPEN.ENDEO TERMS } \\
\hline \multirow{2}{*}{$\begin{array}{l}\text { 18. AVAILABILITY STATEMENT } \\
\text { UnTimited }\end{array}$} & $\begin{array}{l}19 \text { SECUR: } \\
\text { Uncli }\end{array}$ & $\begin{array}{l}\text { CLASS IThis moont } \\
\text { sif ied. }\end{array}$ & 21 NO OF PAGES \\
\hline & $\begin{array}{l}20 \text { SECURI } \\
\text { Uncíc }\end{array}$ & $\begin{array}{l}\text { CLASS IThis oment } \\
\text { Sified }\end{array}$ & $\begin{array}{c}\text { 22. PAICE } \\
\mathrm{S}\end{array}$ \\
\hline
\end{tabular}




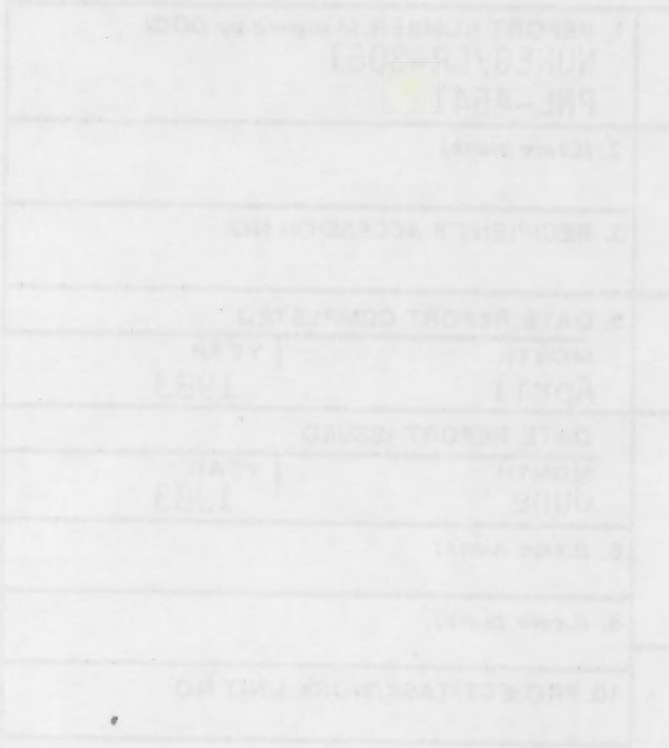

